\title{
Economic Analysis of Isoprene Production from Good Year Scientific Process
}

\author{
Usman Asghar*, Ayesha Masoom, Adan Javed, Ayesha Abbas \\ Department of Chemical Engineering, Wah Engineering College, Wah Cantt., Pakistan
}

Email address:

engr_usman499@yahoo.com (U. Asghar)

${ }^{*}$ Corresponding author

\section{To cite this article:}

Usman Asghar, Ayesha Masoom, Adan Javed, Ayesha Abbas. Economic Analysis of Isoprene Production from Good Year Scientific Process. American Journal of Chemical Engineering. Vol. 8, No. 3, 2020, pp. 63-69. doi: 10.11648/j.ajche.20200803.12

Received: March 28, 2020; Accepted: April 15, 2020; Published: July 13, 2020

\begin{abstract}
The isoprene rubber is very much like natural rubber but made artificially or synthetically. Essentially similar to natural rubber in properties, this rubber may be somewhat weaker because it is not $100 \%$ the cis-isomer. This rubber is used in the same type of products as natural rubber. About $95 \%$ of isoprene production is used to produce cis-1,4-polyisoprene, a synthetic version of natural rubber. The growing demand for fuel efficiency and eco-friendly tires is driving the tire industry and in turn the demand for polyisoprene in the tire industry. The Isoprene Market was valued at USD 1.93 billion in 2015 and is projected to reach USD 2.96 billion by 2021. The isoprene demand in Pakistan will increase up to $24.8 \%$ from 2018 to 2025 reportedly. The isoprene market is increasing due to its increasing applications in tires, conveyor belts, hoses, molded rubber, and also in medical equipment such as gloves and balloons. Isoprene can manufacture from four different processes at commercial scale, but Isoprene from formaldehyde is the prevailing process in the industries. This process has disadvantage of low yield and by-products. So this process is further modified to improve the yield and the operating conditions. But still byproducts are the main problems which decreases the selectivity and yield. To overcome these issues, manufacturing of Isoprene from propylene is studied in plant design project. It is found that this process has $65 \%$ yield and have selectivity of $95 \%$. A cost Analysis was made after the design of different plant equipment, and it is found that a plant of 12000 tons per year has payback period of approximately 4 years.
\end{abstract}

Keywords: Isoprene, Capital Cost, Depreciation, Rate of Return, Pay Back Period

\section{Introduction}

Isoprene is a typical name for the synthetic compound 2methylbuta-1,3-diene. At room temperature, purified isoprene is an exceptionally combustible, colorless liquid that can be effectively ignited. It is shaped normally in animals and plants and is the most common hydrocarbon in the human body. Natural rubber is a polymer of isoprene most often cis1,4-polyisoprene with a molecular weight ranging from 100,000 to $1,000,000$ daltons. Normally, high quality natural rubber additionally contains a couple of percent of different materials, for example, proteins, fatty acids, resins, and inorganic materials [1].

Some natural rubber sources (called gutta percha) are composed of trans-1,4-polyisoprene, a structural isomer of the cis form, with comparative yet not indistinguishable properties. Isoprene is also an important industrial chemical, being readily available as a by-product of the thermal cracking of naphtha or oil. Isoprene, be that as it may, can be an unsafe natural contamination and toxicant when present in abundance. It can form explosive mixtures in air and is profoundly responsive, equipped for polymerizing explosively when heated. The United States Department of Transportation considers isoprene a dangerous material that should be stamped, marked, and moved with proper consideration [2].

About 95 percent of isoprene production is used to produce a synthetic version of natural rubber called polyisoprene or isoprene rubber (IR). Isoprene Rubber or synthetic polyisoprene is used in a wide variety of industries and applications requiring low water swell, high gum tensile strength, good resilience, good tack and high hot tensile. Gum compounds based on IR are used in rubber bands, cut thread, baby bottle nipples, and extruded hose. Black loaded 
compounds of this rubber find use in tires, motor mounts, shock absorber bushings, pipe gaskets, and many other molded and mechanical goods. Mineral filled systems find applications in footwear, sponge, and sporting goods. Recent reports about allergic reactions to proteins present in natural rubber have prompted increased usage of the more pure IR in various applications.

There are two varieties of rubber natural rubber and synthetic rubber. Natural rubber production is mainly involved in three major areas Malaysia, Thailand and Indonesia. In India, rubber production is at the rate of $6 \%$ per annum. Growing and processing natural rubber is considered to be one of the most complex agricultural industries. Natural rubber production combines botany, chemistry, and sophisticated machinery with dexterous skills of the people who harvest the trees.

While natural rubber production is a part of the agricultural industry, products made of synthetic rubber is used for various purposes in the rubber industry. One of the most common rubber product used in agricultural industry is rubber tire. In fact, rubber tires account for $60-70 \%$ of all natural and synthetic rubber used. There are agricultural tires used for various agricultural purposes. The farm tractor, wagon, forklift, backhoe, loader, combines, grain carts, pivots etc. run on rubber tires and these are used for a wide variety of special services such as gardening, moving, municipal machines, terrain vehicles, snow groomers, etc. The agricultural tires are designed with unique properties that help them to operating on different soils composition and moisture content. Another rubber product used in agricultural industry is rubber flooring for stalls and livestock which can take a lot of abuse.

Rubber and rubber products are widely used in the aviation/aerospace industry. The ability to withstand extreme temperatures makes rubber parts ideal for use in aircraft and aerospace applications. Various synthetic rubber can withstand aggressive aerospace fluids, including engine lubrication oils, hydraulic fluids, jet fuels, oxidizers and rocket propellants. Seals fabricated with elastomers like Viton, Hypalon etc. are used regularly in commercial and military aircraft turbine engines, hydraulic actuators, auxiliary power units.

Rubber and rubber products are used in variety of purposes in the automobile industry. In the automotive industry, the presence of rubber is seen in fluid transfer systems, body sealing systems, transmission systems, automotive antivibration, sealants, adhesives \& coatings, O-Rings, molded parts, flat seals, foam and converting products, body parts, spare parts etc. [3-5].

Rubber is a widely used product in the defense industry. Rubber products are used for military use for personnel and equipment mobility in extreme conditions. One of the most common product used in the defense industry is the rubber track. Rubber tracks when installed on military vehicles provide mobility in snow, slush, mud, sand, swamp and tundra conditions. Vehicles with rubber track is available to your law enforcement, search and rescue, or fire fighters and they gain an advantage over adverse weather conditions, remote locations and seemingly impossible terrain.

A wide range of rubber products is used in the textile industry. Rubber calendering is a normal process used in textiles for making various types of fabrics. There are some types of synthetic rubber like a special type of styrene butadiene rubber latex specially developed for textile finishing. Such rubber is specially manufactured using specialty surface active agents which makes it applicable for usage on a wide variety of fabrics like Nylon, Polyester, their blends with cellulosic etc. There are rubber rollers for textile printing, pressure hoses for textile spinning machinery, rubber coating for screen coating applications, rubber molded components for various other applications.

Isoprene can easily form explosive peroxides and can polymerize (uncontrolled reaction) with heating or on contact with many materials, resulting in fires, explosions, and container rupture. For the safe handling, avoid formation of aerosol. Do not breathe vapors/dust. Avoid exposure obtain special instructions before use. Avoid contact with skin and eyes. Smoking, eating and drinking should be prohibited in the application area. Take precautionary measures against static discharges. Provide sufficient air exchange and/or exhaust in work rooms. Container may be opened only under exhaust ventilation hood. Open drum carefully as content may be under pressure. Dispose of rinse water in accordance with local and national regulations. Do not spray on an open flame or any other incandescent material. Take necessary action to avoid static electricity discharge (which might cause ignition of organic vapors). Use only explosion proof equipment. Keep away from open flames, hot surfaces and sources of ignition.

The Isoprene Market was valued at USD 1.93 billion in 2015 and is projected to reach USD 2.96 billion by 2021, at a CAGR of $7.4 \%$, from 2016 to 2021 . About $70 \%$ of isoprene is used to manufacture synthetic rubber called polyisoprene. Polyisoprene has the same basic formula as natural rubber, and thus it is a synthetic version of natural rubber, having the same properties as natural rubber. Also, isoprene is largely used in manufacturing SIS, IIR, and other derivatives. The tire industry is experiencing high growth because of the growing automotive industry.

The isoprene market is increasing due to its increasing applications in tires, conveyor belts, hoses, molded rubber, and also in medical equipment such as gloves and balloons. The demand for isoprene in the automotive industry for manufacturing of polyisoprene is expected to be driven by the growing automotive sales in China and India. The growing demand for fuel efficiency and eco-friendly tires is driving the growth of the tire industry and in turn the growth of the isoprene market.

The growth of the isoprene industry is directly related to the growth of the synthetic rubber industry. Isoprene manufacturers are impacted by the trends in the tire industry and other related synthetic rubber products. The growth in the tire industry is, in turn, dependent on the automotive industry that is growing and projected to witness a global 
sales rise of $60 \%$ by 2020 . The global rubber production has been increasing since 2000 [6-9].

The world's rubber production in 2010 was 23,680 kilotons, which increased to 26,774 kilotons in 2015. This growth in rubber production is projected to continue in the coming years, which will increase the demand for isoprene. The leading isoprene manufactures are expanding their production capacities.

\section{Attractive Opportunities in the Isoprene Market}

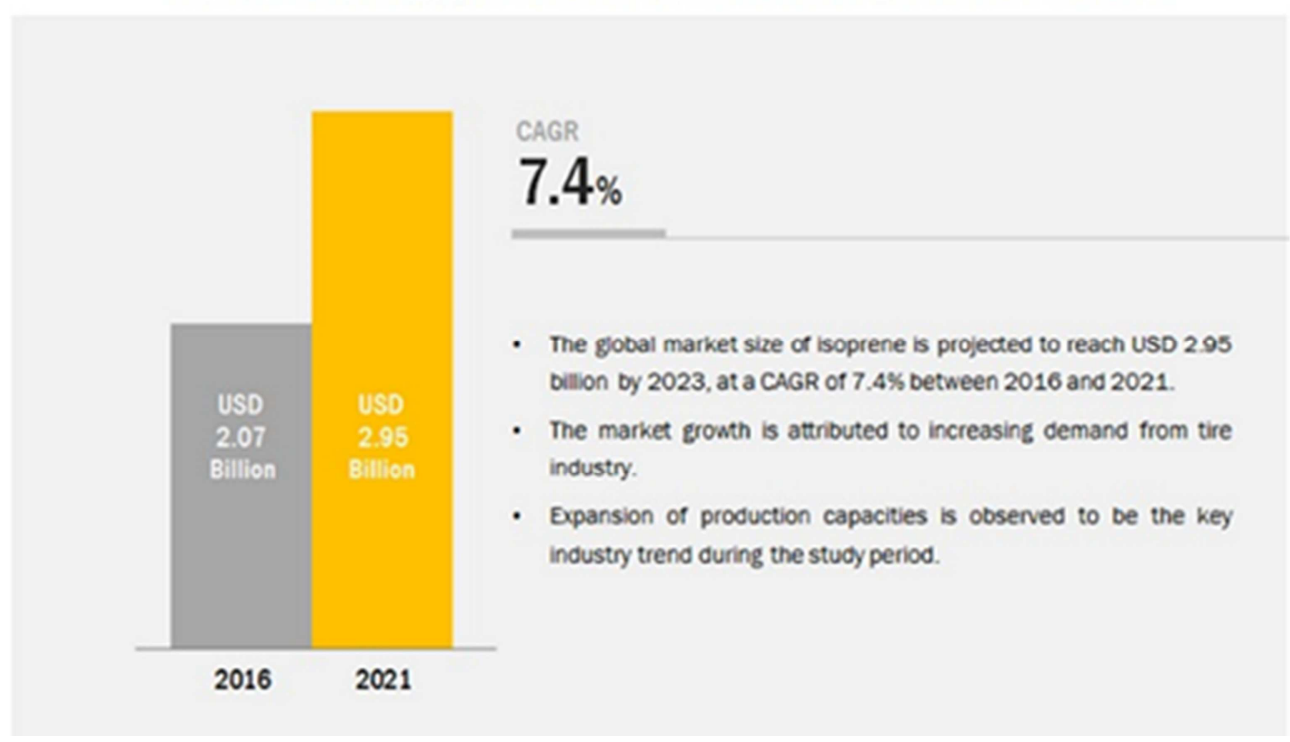

Figure 1. Isoprene globally demand.

Pakistan rubber tyre market size was valued at $\$ 272.10$ million in 2017, and is projected to reach $\$ 1,592.90$ million by 2025, registering a CAGR of $24.8 \%$ from 2018 to 2025 . The key players operating in the Pakistan rubber tyre market include General Tyre and Rubber Co. Ltd., Servis Tyre, the
Goodyear Tyre \& Rubber Company, Bridgestone group, Pirelli Tyre S. p. A, Michelin, Ghauri Tyre \& Tube Ltd., Continental Corporation, Sumitomo Rubber Industries Ltd., and Yokohama Rubber Co., Ltd.

\section{U.S. isoprene market volume by product, $2014-2025$ (Kilo tons)}

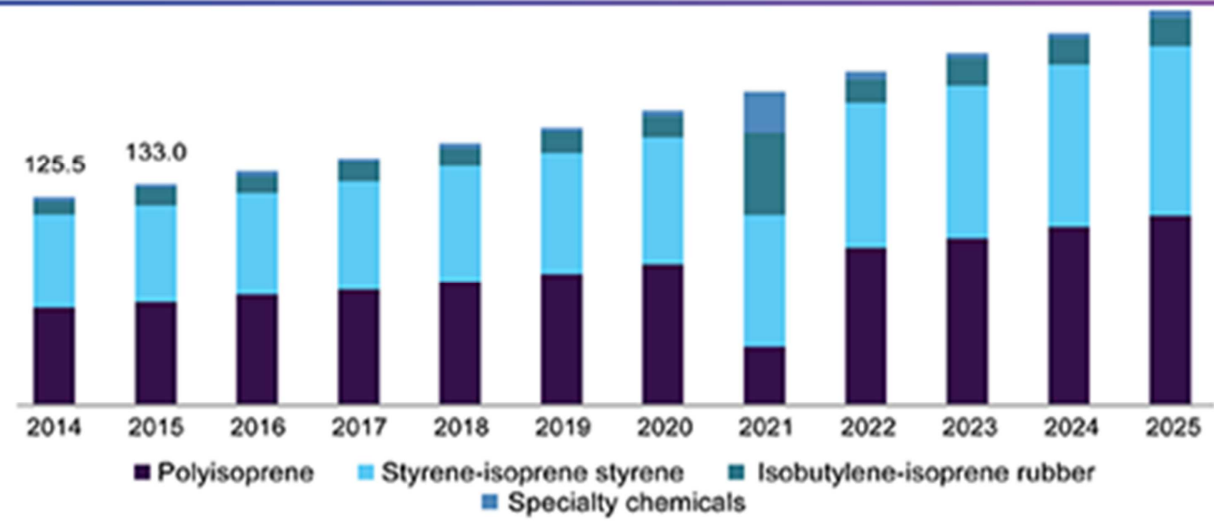

Figure 2. Isoprene market volume by product.

\section{Manufacturing Processes}

There are four manufacturing processes available for the isoprene:

1. Production from isobutylene and formaldehyde.

2. Good year scientific design process (isoprene from propylene).

3. Isoprene from acetone and acetylene.

4. Isoprene synthesis from ethylene and propylene.
Most of the industries are employing "production from isobutylene and formaldehyde" for isoprene processes. This process has low yield (22\%) and high by-product formation. In order to improve yield of this process, different catalysts and operating conditions were used. The improved version of this process produces $60 \%$ yield ang about $85 \%$ selectivity. But good year scientific design manufacturing process yields about $65 \%$ with selectivity more than $95 \%$. This process is preferable as it is economically feasible, produces comparatively high yield, by-products are negligible and has 
negligible environmental impacts. This Process was implemented in the Goodyear Tires in Beaumont, Texas. Good year and Scientific Design Co Inc. collaborated and set a plant for the production of isoprene from propylene. Isoprene is manufacture from propylene using three consecutive reactions (Catalysts: tripropyl aluminium and $\mathrm{HBr}$ with operating conditions of $200^{\circ} \mathrm{C}$ temperature and 202 bar pressure). These are:

1. Dimerization of propylene to obtain 2-methyl-1pentene.

$$
\begin{aligned}
& 2 \mathrm{CH}_{2}=\mathrm{CH}-\mathrm{CH}_{3} \longrightarrow \mathrm{CH}_{2}=\stackrel{\mathrm{CH}_{3}}{=}-\mathrm{CH}_{2}-\mathrm{CH}_{2}-\mathrm{CH}_{3} \\
& \text { Propylene 2-Methyl-1-pentene }
\end{aligned}
$$

2. Isomerization of 2-methyl-1-pentene to obtain 2-methyl2-pentene.

$$
\begin{aligned}
& \mathrm{CH}_{2}=\stackrel{\mathrm{CH}_{3}}{\mathrm{C}}-\mathrm{CH}_{2}-\mathrm{CH}_{2}-\mathrm{CH}_{3} \longrightarrow \mathrm{CH}_{3}-\stackrel{\mathrm{CH}_{3}}{\mathrm{C}}=\mathrm{CH}-\mathrm{CH}_{2}-\mathrm{CH}_{3} \\
& \text { 2-Methyl-1-pentene 2-Methyl-2-pentene }
\end{aligned}
$$

3. Pyrolysis of 2-methyl-2-pentene to obtain isoprene along with methane as a side product.

$$
\begin{aligned}
& \mathrm{CH}_{3}-\stackrel{\mathrm{CH}_{3}}{\mathrm{C}}=\mathrm{CH}-\mathrm{CH}_{2}-\mathrm{CH}_{3} \longrightarrow \mathrm{CH}_{2}-\stackrel{\mathrm{C}}{\mathrm{CH}}=\mathrm{CH}-\mathrm{CH}_{2}+\mathrm{CH}_{4} \\
& \text { 2-Methyl-2-Pentene Isoprene Methane }
\end{aligned}
$$

Since three reactions are involved that have distinct operating conditions as well as catalyst requirements, the process involves a series of reactor-separator-recycle networks [9-12].

The process technology consists of three major blocks namely

1. Dimerization-separator-recycle network (DSR).

2. Isomerization-separator-recycle network (ISR).

3. Pyrolysis-separator-recycle network (PSR).

Process flow diagram for good year scientific design method is given in figure 3 .

\section{Cost Estimation}

A complete plant design was made for a 12000 Tons/year production capacity plant before economic analysis. All the equipment shown in figure 3 are designed, complete material and energy balances were made, all utilities were estimated.

The cost estimate is a "Preliminary Estimate" and is calculated by "Module Costing Method".

The cost indexes used were taken from "Chemical Engineering Magazine” for year 2019.

Total Equipment Cost

Equipment cost was calculated from cost indexes.

Table 1. Total Equipment Cost.

\begin{tabular}{ll}
\hline Equipment & Cost (\$) \\
\hline Heat Exchanger (001) & 76502 \\
Reactor (R-001) & 178389 \\
Flash Column & 41367 \\
Heat Exchanger (002) & 110265 \\
Distillation Column (T-001) & 360574 \\
Distillation Column (T-002) & 65614 \\
Distillation Column (T-003) & 121991 \\
Heat Exchanger (003) & 18222 \\
Reactor (R-002) & 90653 \\
Heat Exchanger (004) & 29778 \\
Distillation Column (T-004) & 49277 \\
Reactor (R-003) & 330969 \\
Quenching Tower & 644143 \\
Heat Exchanger (005) & 278060 \\
Distillation Column (T-005) & 66823 \\
Distillation Column (T-006) & 67623 \\
Pump & 39935 \\
Total & 2570185 \\
\hline
\end{tabular}

Table 2. Fixed Capital Investment.

\begin{tabular}{lll}
\hline Component & Range & Cost (\$) \\
\hline Direct Cost & $100 \%$ of Purchased Cost & 2570185 \\
Purchased Equipment & $39 \%$ of Purchased Cost & 1002372.15 \\
Installation & $28 \%$ of Purchased Cost & 719651.8 \\
Instrumentation and Controls & $31 \%$ of Purchased Cost & 796757.35 \\
Piping & $10 \%$ of Purchased Cost & 257018.5 \\
Electrical & $22 \%$ of Purchased Cost & 565440.7 \\
Buildings & $10 \%$ of Purchased Cost & 257018.5 \\
Yard Improvements & $55 \%$ of Purchased Cost & 1413601.75 \\
Service Facilities & $6 \%$ of Purchased Cost & 154211.1 \\
Land & --- & 7736256.85 \\
Total Direct Cost & & 822459.2 \\
Indirect Cost & $32 \%$ of Purchased Cost & 873862.9 \\
Engineering \& Supervision & $34 \%$ of Purchased Cost & 1696322.1 \\
Construction Expense & --- & 9432578.95 \\
Total Indirect Cost & --- & 471628.948 \\
Total (Direct Cost + Indirect Cost) & 943257.895 \\
Contractor's Fee & $5 \%$ of (Direct + Indirect Cost) & 10847465.8 \\
Contingency & $10 \%$ of (Direct + Indirect Cost) & \\
Fixed Capital investment & --- & \\
\hline
\end{tabular}




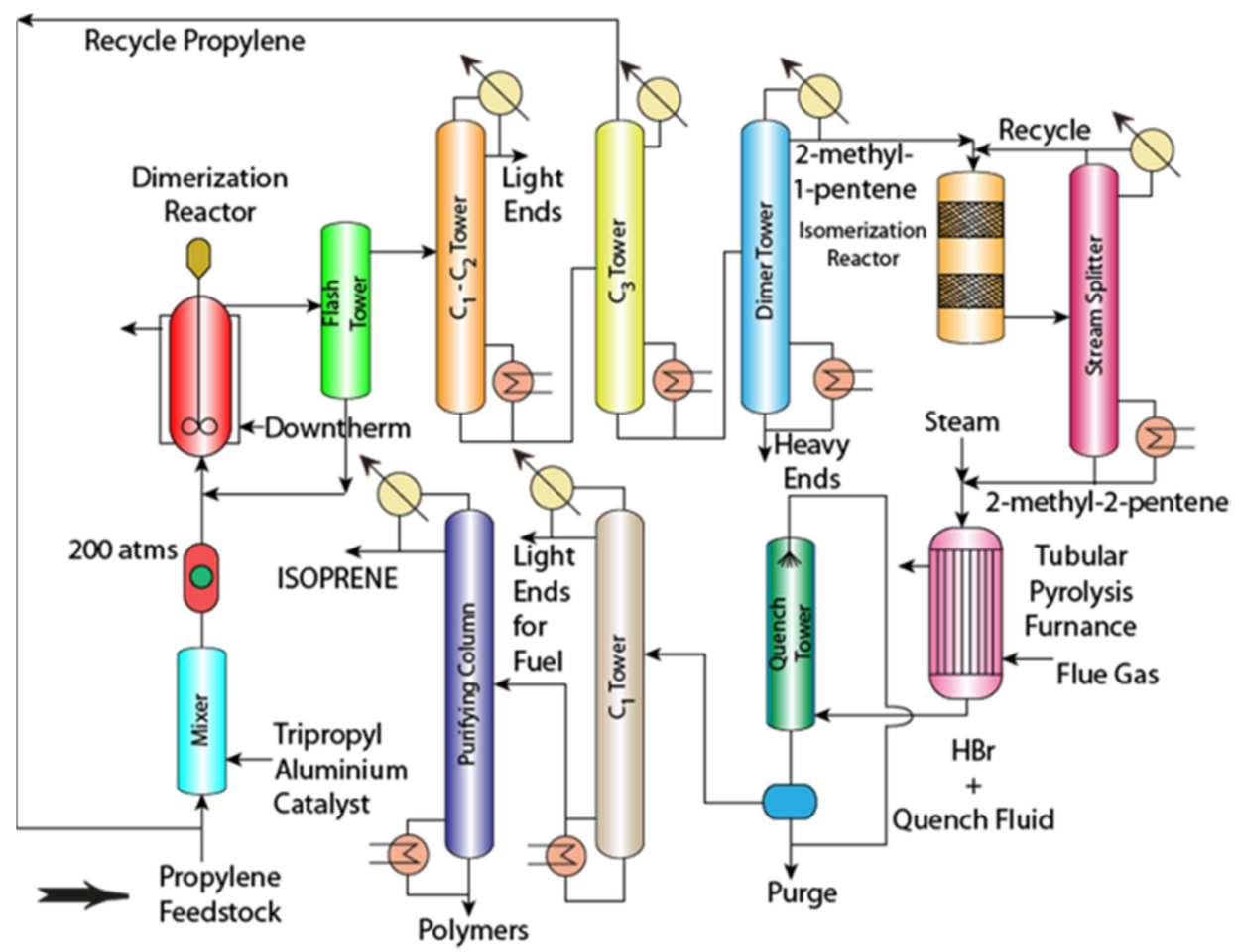

Figure 3. Process flow diagram for the manufacturing of Isoprene from Propylene (Good year scientific Design Method).

Total Capital Investment

Total Capital Investment $=$ Fixed Capital Investment + Working Capital Investment

Fixed Capital Investment $=\$ 10847465.8$

Working Capital Investment $=20 \%$ of $\mathrm{FCI}=$ $20 * 10847465.8=\$ 2169493.159$

Total Capital Investment $=\$ 13016958$

Variable Cost

Variable Cost $=$ Raw Materials Cost + Utilities Cost + Miscellaneous Cost

Raw Materials Cost $=\$ 60022782.57$

Utilities Cost $=\$ 6939260.95$

Miscellaneous Cost $=\$ 75932.26$

Variable Cost $=\$ 67037975.78$

Table 3. Fixed Cost.

\begin{tabular}{lll}
\hline Maintenance & $\mathbf{7 \%}$ of FCI & $\mathbf{7 5 9 3 2 2 . 6 0 5 5}$ \\
\hline Operating Cost of Labor & $10 \%$ of TCI & $0.10 \mathrm{TCI}$ \\
Laboratory Cost & $1.50 \%$ of TCI & $0.015 \mathrm{TCI}$ \\
Supervision Cost & $2 \%$ of TCI & $0.02 \mathrm{TCI}$ \\
Plant Overheads & $5 \%$ of TCI & $0.05 \mathrm{TCI}$ \\
Capital Charges & $10 \%$ of FCI & 1084746.579 \\
Insurance & $1 \%$ of FCI & 108474.6579 \\
Local Taxes & $2 \%$ of FCI & 216949.3159 \\
Royalties & $1 \%$ of FCI & 108474.6579 \\
Fixed Cost & --- & $2277967.816+0.185 \mathrm{TPC}$ \\
\hline
\end{tabular}

Direct Production Cost $=$ Variable Cost + Fixed Cost

$$
\begin{gathered}
=\$ 67037975.78+\$ 2277967.816+0.185(\mathrm{TPC}) \\
=\$ 69315943.6+0.185(\mathrm{TPC})
\end{gathered}
$$

Total production cost $=$ Variable Cost + Fixed Cost +

\section{Overhead Charges}

Overhead charges are $60 \%$ of Direct Production Cost

Overhead charges $=0.60 *(69315943.6+0.185($ TPC $))$

$$
\begin{gathered}
=41589566.16+0.111(\mathrm{TPC}) \\
\text { TPC }=\$ 110905509.8+0.295(\mathrm{TPC}) \\
\text { TPC }-0.295(\mathrm{TPC})=\$ 110905509.8 \\
\text { TPC }(1-0.295)=\$ 110905509.8 \\
\text { TPC }(0.705)=\$ 110905509.8
\end{gathered}
$$

Total Production Cost $=\$ 157312780 / \mathrm{yr}$.

General Expenses

$$
\begin{gathered}
\text { Administrative Cost }=0.04 * 157312780 \\
=\$ 6292511.2
\end{gathered}
$$

Distribution \& Selling Cost $=0.11 * 157312780$

$$
=\$ 17304406
$$

Research \& Development Cost $=0.04 * 157312780$

$$
=\$ 4719383
$$

So, total product cost will become,

$$
\begin{aligned}
& \text { Total Production Cost }=\$ 185629080 / \mathrm{yr} . \\
& \text { Total Production Rate }=120000(\text { ton } / \mathrm{yr} \text {.) }
\end{aligned}
$$

Production Cost 
Production cost $(\$ /$ ton $)=\frac{\text { Total Production } \operatorname{Cost}(\$ / \mathrm{yr} .)}{\text { Total Production Rate }(\text { ton } / \text { yr. })}$

$$
\text { Production Cost }(\$ / \text { ton })=\$ 1547 / \text { ton }
$$

Below this, we cannot sale our product.

And the price of isoprene in market is $2000 \$ /$ ton

Selling Price

Our Selling Price of Product $=\$ 1607 /$ ton

Profitability Analysis

Profit $=$ Selling price - Production cost

$$
=\$ 60 / \text { ton }
$$

Total Production Per Year $=120000$ ton/year

$$
\text { Profit Per Year }=\$ 7210920 / \mathrm{yr}
$$

Total Income

$$
\text { Selling Price }=\$ 1607 / \text { ton }
$$

Total Production Per Year $=120000$ ton/year

Total Income $=\$ 192840000 / \mathrm{yr}$.

Gross Profit

Gross Profit $=$ Total Income - Total Production Cost

$$
=\$ 192840000-\$ 185629080
$$$$
=\$ 7210919.84
$$

Net Profit

Net profit $=$ Gross profit - Depreciation - Taxes

Depreciation

Machinery and equipment $=10 \%$ of FCI

$$
\begin{gathered}
=0.10 * 10847465.8 \\
=\$ 1084746.5
\end{gathered}
$$

Building $=2 \%$ of Building Cost

$$
\begin{gathered}
=0.02 * 10847465.8 \\
=\$ 216949.31
\end{gathered}
$$

Total Depreciation $=\$ 1084746.5+\$ 216949.31$

$$
=\$ 1301695.89
$$

Net Profit before Taxation

Net Profit before Taxation $=$ Gross profit - Depreciation

$$
\begin{gathered}
=\$ 7210919.84-\$ 1301695.89 \\
=\$ 5909223.94
\end{gathered}
$$

Taxes

Tax rate is $34 \%$ of Gross Profit

$$
\begin{aligned}
\text { Taxes } & =0.34 * \text { Gross Profit } \\
& =\$ 2451712.74
\end{aligned}
$$

So, our net profit becomes,

Net Profit $=$ Net profit before taxation - Taxes

$$
=\$ 3457511.202
$$

Rate of Return

$$
\begin{gathered}
\text { Rate of Return }=\frac{\text { Net Profit }}{\text { Total Capital Investment }} \times 100 \\
\text { Rate of Return }=\frac{3457511.202}{110905509.8} \times 100 \\
=26.56 \%
\end{gathered}
$$

Payback Period

$$
\begin{gathered}
\text { Payback Period }=\frac{1}{\text { Rate of Return }} \\
\text { Payback period }=3.8 \approx 4 \text { year }
\end{gathered}
$$

\section{Conclusions}

Isoprene can be manufactured from propylene (Good year Scientific Design Method) because this process has comparatively high yield and selectivity and all catalyst used are inexpensive and easily available. This process has high operating pressure (i.e., 202 Bar) to keep the propylene in liquid phase. This is very safe process as compared to other available manufacturing processes.

Economic Analysis was made for this process on plant of 12000 Tons/year capacity. It was found that this has $26.5 \%$ ROR with pay back period of approximately 4 years that make this process quite feasible and attractive to invest.

\section{References}

[1] Sharkey, Thomas D. (1996). "Isoprene synthesis by plants and animals". Endeavour. 20 (2): 74-78. doi: 10.1016/0160-9327 (96)10014-4.

[2] Williams, C. Grenville (1860). "On isoprene and caoutchine". Proceedings of the Royal Society of London. 10: 516-519. doi: 10.1098/rspl.1859.0101.

[3] M. J. Loadman (2012-12-06). Analysis of Rubber and Rubberlike Polymers. Springer. p. 10. ISBN 9789401144353.

[4] Guenther, A.; Karl, T.; Harley, P.; Wiedinmyer, C.; Palmer, P. I.; Geron, C. (2006). "Estimates of global terrestrial isoprene emissions using MEGAN (Model of Emissions of Gases and Aerosols from Nature)". Atmospheric Chemistry and Physics. 6 (11): 3181-3210. doi: 10.5194/acp-6-3181-2006.

[5] A source of haze, ScienceNews, August 6th, 2009.

[6] The Goodyear Tire and Rubber Company. Industrial hygiene data. August 2000 
[7] Gelmont, David; Stein, Robert A.; Mead, James F. (1981). "Isoprene — the main hydrocarbon in human breath". Biochemical and Biophysical Research Communications. 99 (4): 1456-1460. doi: 10.1016/0006-291X(81)90782-8.

[8] H. M. Lybarger, Kirk-Othmer Encyclopedia of Chemical Technology, Isoprene, vol. 14, Fourth ed., Wiley, New York, NY, 1995, pp. 934-952.

[9] Organic Carbon Compounds Emitted By Trees Affect Air Quality, ScienceDaily, Aug. 7, 2009.

[10] King, Julian; Koc, Helin; Unterkofler, Karl; Mochalski, Pawel; Kupferthaler, Alexander; Teschl, Gerald; Teschl, Susanne; Hinterhuber, Hartmann; Amann, Anton (2010). "Physiological modeling of isoprene dynamics in exhaled breath". Journal of Theoretical Biology. 267 (4): 626-637. arXiv: 1010.2145. doi: 10.1016/j.jtbi.2010.09.028. PMID 20869370.
[11] Vickers, Claudia E.; Possell, Malcolm; Cojocariu, Cristian I.; Velikova, Violeta B.; Laothawornkitkul, Jullada; Ryan, Annette; Mullineaux, Philip M.; Nicholas Hewitt, C. (2009). "Isoprene synthesis protects transgenic tobacco plants from oxidative stress". Plant, Cell \& Environment. 32 (5): 520-531. doi: 10.1111/j.1365-3040.2009.01946.x. PMID 19183288.

[12] The Chemical Engineering Magazine.

[13] Benjamin, Michael T.; Sudol, Mark; Bloch, Laura; Winer, Arthur M. (1996). "Low-emitting urban forests: A taxonomic methodology for assigning isoprene and monoterpene emission rates". Atmospheric Environment. 30 (9): 1437 1452. doi: 10.1016/1352-2310(95)00439-4.

[14] J. L. McGraw, Letter to the US National Toxicology Program. Information on the scope of human exposures to workers in the monomer/polymer industry in the US. June 24, 1998. 